\title{
The Impact of Job Satisfaction and Organizational Commitment on Intention to Turnover in the Sri Lankan Hospitality Industry: Perceptions from the Generation Y View Point
}

\author{
G.D.N. Perera \\ Senior Lecturer \\ Faculty of Management Studies and Commerce, \\ University of Sri Jayewardenepura, Sri Lanka \\ dinokagnp@sjp.ac.lk \\ G.T. Madagamage \\ Senior Lecturer \\ Faculty of Management Studies and Commerce, \\ University of Sri Jayewardenepura, Sri Lanka \\ geetha@sjp.ac.lk
}

Cite this article: Perera, G.D.N and Madagamage, G.T. (2018), Impact of Job Satisfaction and Organizational Commitment on Intention to Turnover in the Sri Lankan Hospitality Industry: Perceptions from the Generation Y View Point, Sri Lankan Journal of Human Resource Management, Vol. 8, No. 1, pp. 23-35. 


\begin{abstract}
This study investigated the impact of job satisfaction and organizational commitment on intention to turnover according to the perceptions from generation $Y$ in the Sri Lankan hospitality industry. The methodological approach of this study was based on the quantitative approach and the type of investigation was correlational. The respondents were limited to 256 generation $Y$ employees who were employed during the period of the study. Data composed of self-administered questionnaire containing 19 closed statements with a five point Likert type scale. The descriptive statistics, correlation and regression analysis were applied among dependent construct and independent constructs. The results of the study revealed that there are a significant impact of job satisfaction (15\%), and a significant impact of organizational commitment (4.8\%) on intention to turnover, according to the perception of generation $Y$ employees in the Sri Lankan hospitality industry. Further, the findings show that there was a significant joint impact of job satisfaction and organizational commitment on intention to turnover (15.5\%). Moreover, the statistical results relating to hypotheses, revealed that there was a moderate negative relationship between job satisfaction and intention to turnover $(r=.-0.467 p<0.01)$. Also, there was $a$ weak negative relationship between organizational commitment and intention to turnover among generation $Y$ respondents of Sri Lankan hospitality industry $(r=.-0.441, p<0.01)$. Implications of the findings and suggestions for future research studies have been presented.
\end{abstract}

Key Words: Generation Y, Hospitality Industry, Intention to Turnover, Job Satisfaction, Organizational Commitment

\title{
Introduction
}

Sri Lankan hospitality industry is a crucial driver of economic growth and advancement in the country. According to Sri Lanka Tourism Development Authority sources, hospitality industry's direct contribution to Sri Lankan gross domestic product in 2017 was about 4.5\%(Annual Statistical Report, 2017). This highlights that the Sri Lankan hospitality industry has continued to develop and play a momentous role in the economy. As a result, Sri Lankan hospitality industry had an unremitting competitive advantage in the services they provided; it wanted highly satisfied, committed and engaged employees. In recent times, many hotels required business oriented talented employees to procure, improve and retain (Joo and McLean, 2006).

In the present situation of energetic hospitality environments, many hotels are facing a problem of intention to turnover of their valuable employees. Therefore, previous researchers in varied fields have been attentive in employees' turnover intention (Lambert et al., 2001). According to Agapitos et al. (2015) there are various reasons for Intention to Turnover (IT) of employees. However, reviewing an existing literature (Yucel, 2012; Baotham et al. 2010) two constructs play vital role in impacting on IT, which were Job Satisfaction (JS) and Organizational Commitment (OC). So, investigating the hospitality industry, specially paying attention to classified hotels (five star, four star, three star and less than three stars) -approved by the Tourist Board in Sri Lanka is significant in the present context. 
There has been considerable empirical research on JS, OC and IT in different industries in various countries (Ahmad and Omar2010; Costen and Salaza, 2011). Therefore, there is no shortage of literature in the above concepts. But, these studies have varied widely in terms of context, objective and methods used. However, the studies investigating JS, OC and its impact on IT in the Sri Lankan context, especially in the classified hospitality industry and generation $\mathrm{Y}$ employees are very rare. Thus, the attention of the existing study is to investigate the impact of above mentioned constructs in the Sri Lankan hospitality industry context. Hence, studying of these constructs is vital for the success of the hospitality industry in Sri Lanka and fills the gap in the empirical knowledge relating to JS and OC impact on IT in Sri Lankan hospitality industry generation $\mathrm{Y}$ employees.

The problem addressed in this study is: do job satisfaction and organizational commitment impact on intention to turnover of generation $Y$ employees in the Sri Lankan classified hospitality industry?

Based on the disagreement open here and considering the above research problem, the following research objectives were derivative:

1. To examine how job satisfaction and organizational commitment impact on the intention to turnover, according to the perception of generation $Y$ employees in the Sri Lankan hospitality industry.

2. To identify the joint impact of job satisfaction and organizational commitment on intention to turnover, according to the perception of generation $\mathrm{Y}$ employees in the Sri Lankan hospitality industry.

This paper makes some vital contributions to the prevailing literature. For instance, this study was conducted in the Sri Lanka, still a developing country, thus the outcomes contribute to the assessment of possible similarities or variations in the outcomes of JS, $\mathrm{OC}$ and IT across studies. The subsequent fragments were examining the applicable literature to help to develop research framework, explanation of the methodology, measures, results and conclusions.

\section{Generation Y}

\section{Literature Review}

From1980s to the early $90 \mathrm{~s}$ born persons are considered as generation $\mathrm{Y}$ cluster (Raymond and Yeung, 2016). According to Solnet and Hood (2011) their attitudes are drastically changed compared to the earlier generation since they matured up in a domain with global economic prosperity and low joblessness. Further, they highlighted that experiences of work affect the generation $Y$ attitudes. According to Bamford (2012) highlighted generation $Y$ employees have sound innovative and technological skills and they are searching for more rewards and suppose to receive continued response. Prior studies of other countries (Bamford, 2012; Richardson, 2009) mentioned that generation $\mathrm{Y}$ employees are more concerned about the pay, promotion opportunities and close relationships with peers. Therefore, it is believed that generation Y IT were influenced by JS and OC. Thus, it is required to scrutinize the generation Y's views relating to JS, OC and IT in the Sri Lankan hospitality industry. 


\section{Job Satisfaction}

Job satisfaction is designated as the spirits of workforce sensing from the evaluation of their job and can be negative, positive, or average (Perera, etal.2014). Robbins and Judge (2009,p. 83) defined JS as "a positive feeling about a job resulting from an evaluation of its characteristics." Further, Kreitner and Kinicki (2007) defined JS as the "extent to which someone likes his or her job." Furthermore, Nelson and Quick (2009, p. 56) defined it as "a pleasurable or positive emotional state resulting from the appraisal of one's job or job experiences." According to Stammen (2003), directed happiness and satisfied employees continuously support to develop organizational image, organizational performance as well as individual performance. This paper reflects Robbins and Judge (2009, p. 83) definition as a working definition of JS.

\section{Organizational Commitment}

According to the assessment of previous researchers $O C$ is a personal relationship as a result of frequent contact among employees and employers and it is established that connection is stronger with full time employees than part time employees (Chen, Tsui, and Farh, 2002). Many relevant studies on this acknowledged OC as a multidimensional construct and a tridimensional model was developed by Meyer and Allen (1997). Further, they defined $O C$ as a mental state that symbolizes the worker's affiliation with the workplace and has inferences for the judgment to continue relationship in the workplace. Furthermore, literature stated that when employees are more qualified and larger the organization they work for, commitment would be more towards the organization (Passarelli, 2011). This paper considered Meyer and Allen's (1997) definition as the working definition of OC.

\section{Intention to Turnover}

Intention to turnover is an influential forecaster of an employee's future behavior and actual turnover (Park and Kim, 2009). The IT is an employee's opinion that he/she would leave the organization (Kahumuza and Schlechter, 2008) and is regarded as the final step in the path of a decision-making of an employee to look for other engagement (Park and Kim, 2009).IT can be demarcated as the last in a series of withdrawal cognitions, a set to which thinking of leaving and intent to search for substitute engagement also belong (Tett and Meyer, 1993). The IT can be initiated by the persons' deleterious views and outlooks relating to their post and organization (Shwu-Ru and Ching-Yu, 2010). In this study, IT was defined as generation $Y$ employees' willingness to leave from the current organization in the Sri Lankan hospitality industry.

\section{Research Framework}

The research framework of the study had three variables which were major constructs in managing people at work. This study considered intention to turnover as the dependent variable and JS and OC as the independent variables (Refer to Figure 1). 
Figure 1: Research Framework

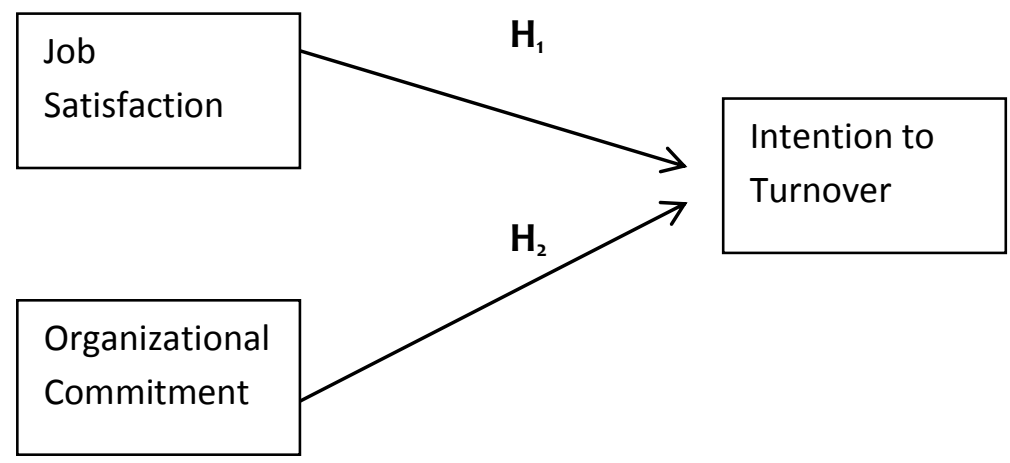

\section{Job Satisfaction and Intention to Turnover}

According to the meta-analysis of Hellman (1997), who completed 50 studies, had the purpose to obviously display the link that occurs between JS and IT. The outcomes proposed a relation considerably changed of zero and negative in studies recognized in the United States of America (Winterton, 2004).Du et al. (2006) revealed that the JS construct related with IT significantly. Further, preceding studies found that the variable JS showed a negative correlation with the IT significantly (Brashear et al., 2003; Ferreira and Siqueira, 2005; Mudor and Tooksoon, 2011). According to Moore (2000) employees IT upsurges due to lack of JS relating to the job and organization. Consideration of the existing literature of empirical evidence given resulted in formulating the first hypothesis for this study and it is:

$\mathrm{H}_{1}$ : There is a negative relationship between job satisfaction and intention to turnover of generation $\mathrm{Y}$ employees in the Sri Lankan hospitality industry.

\section{Organizational Commitment and Intention to Turnover}

Previous studies (Kusluvan and Kusluvan, 2000;Richardson, 2009) signpost that the bulk of employees relating to generation $Y$ group do not engage in hospitality sector as a career due to deficiency of commitment, being biased of poor working environment and reduced required motivation to regularly provide excellence. Bartol (1979) suggested that employee IT is affected by OC. Employees who have commitment and a positive point of view about their organization, depict low IT and thus reduce turnover rates in the organization (Cho et al., 2009).It is substantiated that OC of a particular employee would be a main indicator for that employee's decision to stay or leave the organization. Ali and Baloch (2009) stated that OC has a strong negative relationship on IT. Solnet, Kralj and Kandampully (2012) stated that generation Y employees' OC was the lowest and it is considerably related to IT. Accordingly, the second hypothesis is formulated as:

$\mathrm{H}_{2}$ : There is a negative relationship between organizational commitment and intention to turnover of generation $Y$ employees in the Sri Lankan hospitality industry. 


\section{Methodology}

In this study deductive approach was selected and the theory and the literature guided the development of the above mentioned objectives of the study, construction of the research framework and derivation of hypotheses. The epistemological position of this study is positivism because this study involved a research framework and formulated the hypotheses based on theory. This study included classified hotels list of tourist board of Sri Lanka. The researchers wanted to take all classified hotels in Sri Lanka numbering 138 to conduct the survey. However it was possible to get permission to collect data from 67 classified hotels to conduct the survey.

Generation $\mathrm{Y}$ employees who were being employed during the time of the study in the classified hospitality industry in Sri Lanka were considered as the target population and data were gathered through a quantitative cross sectional survey method. Each member had the equal chance in getting selected to the sample. The complete list of generation $Y$ employees in the hospitality industry was not available prior to data collection. As a result, non-probability sampling method was used to gather data. With regard to the type of non-probability sampling, convenient sampling method was selected for this study. Convenient sampling provides the availability and quickness in which data can be gathered (Sekaran and Bougie, 2010). Furthermore, this method seems to be more rational due to the time limit. Many hotels' top management gave the consent to issue the prepared questionnaires and exhibited their awareness regarding the scope of the study.

Questionnaires were sent through Google form as well as distributed by hand to the human resource manager in the respective hotel and collected on predetermined dates. The researcher was not able to communicate with the respondents directly and the human resource managers provided guarantee to the researchers that employees were assured of confidentiality and anonymity. The data were scrutinized using the computerbased statistical data analysis package, SPSS (version 23.0) and Regression Analysis. Univariate, bivariate and multivariate methods were used for the purpose of data analysis of this study.

\section{Measures}

The questionnaire was divided into four sections as follows:

Demographic Factors: This section considered to solicit information about the generation $\mathrm{Y}$ respondents relating to highest educational qualification, gender, job position, experience in hotel industry and hotel category.

Job Satisfaction: JS was measured by using the instrument developed by Thomas and Tymon (1994). Data were collected concerning the generation $Y$ employees' perceptions of certain job attributes, their attitudes concerning satisfaction with pay, satisfied with promotion opportunities, satisfied relationships with other employees, satisfied with job assignments on a 5-point Likert-type scale that ranged from 1"strongly disagree" to 5"strongly agree." 
Organizational Commitment: Being consistent with previous studies, OC was measured with the Meyer and Allen (1997) eleven-item scale. The instrument focuses on the three dimensions of OC, i.e. affective commitment- emotional connection to be a part of the organization, continuance commitment- perception of the high cost linked with leaving the organization, and normative commitment- sense of social ties and obligation that they should stay in the organization. Respondents expressed their agreement or disagreement on a 5-point Likert-type scale that fluctuated from 1 "strongly disagree" to 5 "strongly agree."

Intention to Turnover: IT was measured by using the instrument developed by Rosin and Karabik. (1991) which is a 4-item scale including preparation to leave job within next six months, actively searching for a job right now, thoughts about leaving this organization and at this time quit the job if it were feasible. Reactions to these items were made on a 5-point Likert-type scale ranging from 1 "strongly disagree" to 5 "strongly agree."

\section{Results}

After reviewing the completed questionnaires from generation $Y$ respondents (256), two had missing data and were removed from the data analysis purpose. Kaiser-Meyer-Olkin (KMO) was used to measure the sample adequacy of the study. With reference to Table 1 , the values of KMO were above the cutoff point of 0.5 which indicated a good range of sample adequacy and Bartlett's test of Sphericity values of constructs were significant for all the constructs.

The external reliability of the constructs was tested by Test- retest method. The test was carried out using 30 respondents from generation $\mathrm{Y}$ respondents of Sri Lankan hospitality industry within a two-week interval. Correlation coefficients of the Test retest of the JS, OC and IT constructs were $0.834,0.845$ and 0.823 respectively and it indicated that each construct had a high external reliability.

Table 1: KMO and Bartlett's Test of Sphericity

\begin{tabular}{|c|c|c|c|c|}
\hline & $\begin{array}{l}\text { Job } \\
\text { Satisfaction }\end{array}$ & $\begin{array}{l}\text { Organizational } \\
\text { Commitment }\end{array}$ & $\begin{array}{l}\text { Intention to } \\
\text { turn over }\end{array}$ \\
\hline \multicolumn{2}{|c|}{$\begin{array}{l}\text { KMO measure of } \\
\text { sampling adequacy }(> \\
.5)\end{array}$} & .703 & .875 & .841 \\
\hline \multirow{3}{*}{$\begin{array}{l}\text { Bartlett's } \\
\text { Test of } \\
\text { Sphericity } \\
(\mathbf{P}<.05)\end{array}$} & $\begin{array}{l}\text { Approx. } \\
\text { Chi } \\
\text { Square }\end{array}$ & 456.149 & 1241.421 & 825.486 \\
\hline & $\mathrm{df}$ & 6 & 55 & 6 \\
\hline & Sig. & .000 & .000 & .000 \\
\hline
\end{tabular}

Reliability or internal consistency was measured for each construct by using Cronbach's Alpha. The results of the Cronbach's Alpha were specified in Table 2 which recommended that the internal reliability of each construct was satisfactory. Content validity was ensured through reviewing literature comprehensively. Composite Reliability $(C R>0.7)$ and Average Variance Extracted (AVE $>0.50)$ were used to ensure the convergent validity 
(Hair, Ringle, and Sarstedt, 2011).The results presented in Table 2 show that both CR and AVE values exceeded the respective threshold values ensuring the convergent validity.

Table 2: Results of Reliability and Validity

\begin{tabular}{|l|c|c|c|}
\hline Constructs & $\begin{array}{l}\text { Average Variance } \\
\text { Extracted }\end{array}$ & $\begin{array}{l}\text { Composite } \\
\text { Reliability }\end{array}$ & Cronbach's Alpha \\
\hline Job Satisfaction & 0.62 & 0.81 & 0.830 \\
\hline Organizational Commitment & 0.67 & 0.86 & 0.883 \\
\hline Intention to Turnover & 0.61 & 0.82 & 0.931 \\
\hline
\end{tabular}

This study opted for Skewness and Kurtosis as the assessment measures of the normality. The Skewness values of JS, OC and IT were-0.396,-1.586 and 1.008 correspondingly as well as Kurtosis values of JS, OC and IT were $0.449,4.0318$ and 0.597 in sequence. Therefore, in this study the Skewness values were less than 2 and Kurtosis values were less than 7 , suggesting that there were no serious violations of the normality (Curran, West and Finch, 1996).

Considering the Table 3, demographic profile of 254 generation $\mathrm{Y}$ employees, 44\% percent of generation $Y$ respondents belonged to $1986-1991$ year period. $31 \%$ and $25 \%$ respondents' birth years were fitted to 1980-1985 and 1992-1997 period respectively. The respondents' educational level as indicated that most of the generation $Y$ had diploma representing $51 \%, 23 \%$ had degree while $20 \%$ passed $A / L$ examination and few of them had masters representing $6 \%$.

Sixty nine (69\%) percent of the generation $\mathrm{Y}$ respondents were males with31\%females. Thirty-seven percent of the respondents were executives, 20\% were supervisors, $15 \%$ were assistant managers, $14 \%$ were managers and 6\% were residence managers.40\% generation $Y$ respondents had 6-10 years of service and 35\% had less than five year experience in the hotel industry. However $20 \%$ and $5 \%$ respondents had $11-15$ years and more than 15 years' experience in hotel industry respectively. Most of the respondents (44\% and 34\%) were from four stars and five stars hotels respectively. $14 \%$ of the respondents were from three star hotels while a minority of $8 \%$ were from less than three stars hotels.

Hypotheses were tested with Correlation Analysis. From the results, there was a moderate negative relationship between JS and IT among generation $\mathrm{Y}$ respondents of Sri Lankan hospitality industry $(r=.-0.467, p<0.01)$ and also there was a significant negative relationship between organizational commitment and intention to turnover among generation $\mathrm{Y}$ respondents of Sri Lankan hospitality industry $(r=.-0.441, p<0.01)$. 
Table 3: Demographic Profile of the Respondents

\begin{tabular}{|l|c|c|}
\hline Demographic Factors & Frequency & Percentage (\%) \\
\hline Birth Year & & \\
$1980-1985$ & 78 & 31 \\
1986-1991 & 112 & 44 \\
1992-1997 & 64 & 25 \\
\hline Highest Educational Qualification & & \\
A/L Examination & 50 & 20 \\
Diploma & 130 & 51 \\
Degree & 58 & 23 \\
Master & 15 & 06 \\
\hline Gender & 174 & \\
Male & 80 & 69 \\
Female & & 31 \\
\hline Job Position & 73 & \\
Supervisor & 93 & 28 \\
Executive & 38 & 37 \\
Assistant Manager & 36 & 15 \\
Manager & 14 & 14 \\
Residence Manager & & 06 \\
\hline Experience in Hotel industry & 90 & \\
Less than 5 & 100 & 35 \\
Between 6-10 & 51 & 40 \\
Between 11-15 & 13 & 20 \\
More than 15 & & 05 \\
\hline Hotel Category & 20 & \\
Less than 3 star & 36 & 08 \\
3 star & 112 & 14 \\
4 star & 86 & 44 \\
5 star & & 34 \\
\hline
\end{tabular}

Regression analysis was done to discover the impact of JS on IT among generation $Y$ respondents of Sri Lankan hospitality industry. As shown in Table 4 of the model summary, the value of $R$ square is 148 which reflect that IT is explicated by about $15 \%$ through variation in JS. The $\mathrm{p}$-value is less than .001.This means that JS has a significant impact on IT. Further, Regression analysis was done to discover the impact of OC on IT among generation $Y$ respondents of Sri Lankan hospitality industry. When considered the Table 4, R Square value is 0.78 ; therefore, only $7.8 \%$ of the total variations in IT can be explained by the OC.

Table 4: Regression Analysis about the Impact of Job Satisfaction and Organizational Commitment on Intention to Turnover

\begin{tabular}{|l|l|l|l|l|l|}
\hline Model & $\mathbf{R}$ & $\begin{array}{l}\mathbf{R} \\
\text { Square }\end{array}$ & $\begin{array}{l}\text { Adjusted R } \\
\text { Square }\end{array}$ & Sig. & $\begin{array}{l}\text { Std. Error of the } \\
\text { Estimate }\end{array}$ \\
\hline JS & .385 & .148 & .145 & .000 & .85995 \\
\hline OC & .280 & .078 & .075 & .000 & .89458 \\
\hline
\end{tabular}

The joint impact of JS and OC on IT was tested through the multiple regression analysis. The outcome showed that the multiple regression coefficients (R) of the two independent variables of JS and OC and the IT were .394 and the R Square was .155. It indicates that about $15.5 \%$ of the variance ( $R$ Square) in the IT was explained by the two 
variables together. Thus, there is statistical confirmation to claim that JS and OC jointly and significantly explain the variance in the IT.

\section{Discussion and Conclusion}

This study was a systematic attempt to provide empirical evidence about the behaviours of three major constructs i.e. JS, OC, and IT in relation to generation $\mathrm{Y}$ employees in Sri Lankan hospitality industry. Specifically this study investigated the impact of JS and OC on IT among generation $\mathrm{Y}$ respondents (15\% and $7.8 \%$ respectively) in Sri Lankan hospitality industry and examined the joint impact of JS and OC on IT (15.5\%). The study had two objectives which were achieved. The results of the study were steady with the empirical and theoretical studies (Albrecht et al., 2015; Rich et al., 2010; Anitha, 2014). Substantiation of the two hypotheses in the study with regard to a negative relationship between JS and IT and a negative relationship between OC and IT of generation $Y$ employees in Sri Lankan hospitality industry were consistent with the previous studies (Ali and Baloch, 2009; Cho et al., 2009; Winterton, 2004). It was found furthermore that JS and IT jointly explain a significant percentage of variance of IT of generation $Y$ employees in Sri Lankan hospitality industry.

It is the obligation of the management, particularly top managers of the hospitality industry to consider improving the JS and OC related factors and reducing the IT of the generation $Y$ employees in their endeavor to reach the accomplishment of strategic goals of the hotels and then to strive for the hospitality sector growth and success. Generation $\mathrm{Y}$ employees are to be influenced to become more satisfied with their jobs and more committed to their organizations affectively, continually, and normatively. In this regard adaptation of various HRM strategies appropriately becomes essential hoping that the IT of the generation $\mathrm{Y}$ employees gets minimized.

Further studies are suggested in respect of considering the other sectors of the country. It will be useful and interesting to investigate existence of mediating and moderating variables explaining and having contingent effects on the relationship between JS and IT and the relationship between $\mathrm{OC}$ and IT of generation $\mathrm{Y}$ employees.

\section{References}

Agapito, P.R. PolizziFilho, A. and Siqueira, M.M.M. (2015), Wellbeing at Work and Perception of Success in Career as Antecedents of Turnover Intention, Revista Mackenzie administration, Vol. 16, No. 6, pp. 71-93.

Ahmad, A. and Omar, Z. (2010), Perceived Family-Supportive Work Culture, Affective Commitment and Turnover Intention of Employees, Journal of American Science, Vol. 6, No.12, pp. 839-846.

Albrecht, S. L. Bakker, A. B. Gruman, J. A. Macey, W. H. and Saks, A. M. (2015), Employee Engagement, Human Resource Management Practices and Competitive Advantage: An Integrated Approach. Journal of Organizational Effectiveness: People and Performance, Vol. 2, No. 1, pp. 7-35.

Ali,N. and Baloch, Q.B (2009), Predictors of Organizational Commitment and Turnover Intention of Medical Representatives (An Empirical Evidence of Pakistani Companies), Journal of Managerial Sciences, Vol. 3, No.2, pp. 262-273. 
Anitha, J. (2014), Determinants of Employee Engagement and Their Impact on Employee Performance, International Journal of Productivity and Performance Management, Vol. 63, No.3, pp. 308-323.

Annual Statistical Report (2017), Sri Lanka Tourism Development Authority, Sri Lanka.

Bamford, K.L. (2012), "Undergraduate Student Perceptions of a Career in the Tourism and Hospitality Industry in New Zealand", Master of Tourism Thesis, University of Otago, Dunedin.

Baotham, S. Hongkhuntod, W. and Rattanajun, S. (2010), The Effects of Job Satisfaction and Organizational Commitment on Voluntary Turnover Intentions of Thai Employees in the New University, Review of Business Research, Vol. 10, No. 1, pp. 73-82.

Bartol, K.M. (1979), Professionalism as a Predictor of Organizational Commitment, Role Stress, and Turnover: A Multidimensional Approach, Academy of Management Journal, Vol. 22, No. 4, pp. 815-821.

Brashear, T.G. E.L. White and C. Chelariu (2003), An Empirical Test of Antecedents and Consequences of Salesperson Job Satisfaction among Polish Retail Sales people, Journal of Business Research, Vol. 56, No. 12, pp. 971-978.

Chen, Z. X. Tsui, A. S. and Farh, J. L. (2002), Loyalty to Supervisor versus Organizational Commitment: Relationships to Employee Performance in China, Journal of Occupational and Organizational Psychology, Vol. 75, No. 3, pp. 339-356.

Cho, S. Johanson, M.M. and Guchait, P. (2009), Employees Intent to Leave: A Comparison of Determinants of Intent to Leave Versus Intent to Stay, International Journal of Hospitality Management, Vol. 28, No. 3, pp. 374-381.

Costen, W. M. and Salazar, J. (2011), The Impact of Training and Development on Employee Job Satisfaction, Loyalty, and Intent to Stay in the Lodging Industry, Journal of Human Resources in Hospitality \& Tourism, Vol. 10, No.4, pp. 273-284.

Curran, West and Finch (1996), The Robustness of Test Statistics to Non-normality and Specification Error in Confirmatory Factor Analysis, Psychological Methods, Vol. 1, No. 1, pp. 16-29.

Du,J.J.Zhou, J. Lui, C.E. and Picken, D. (2006), Exploring Turnover Intention of Construction Managers in China, Journal of Construction Research, Vol. 7, No.2, pp. 191-205.

Ferreira, M.L.C.B. and Siqueira, M.M.M. (2005), Antecedents of Turnover Intention: a Psychosocial Model Study Organizations in Context, Vol. 1, No.2, pp. 47-67.

Hair, J. F. Ringle, C. M. and Sarstedt, M. (2011), PLS-SEM: indeed, a silver bullet, Journal of Marketing Theory and Practice, Vol. 19, No.2, pp. 139-151.

Hellman, C.M. (1997), Job Satisfaction and Intent to Leave, Journal of Sociology and Psychology. Vol. 13, No.7, pp. 677-689.

Joo, B. and McLean, G.N. (2006), Best Employer Studies: a Conceptual Model from a Literature Review and a Case Study, Human Resource Development Review, Vol. 5, No. 2, pp. 228-57.

Kahumuza, J. and Schlechter, A.F. (2008), "Examining the direct and some mediated relationships between perceived support and intention to quit", Management Dynamics, Vol. 17, No. 3, pp. 2-19.

Kreitner, R. and Kinicki, A. (2007), Organizational Behavior, $7^{\text {th }}$ ed. McGraw -Hill Irwin, Boston, MA. 
Kusluvan, S. and Kusluvan, Z. (2000), Perceptions and Attitudes of Undergraduate Tourism Students Towards Working in the Tourism Industry in Turkey, Tourism Management, Vol. 21, No. 3, pp. 251-269.

Lambert, E.G. Hogana, N.L. and Bartona, S.M. (2001), The Impact of Job Satisfaction on Turnover Intent: a Test of a Structural Measurement Model using a National Sample of Workers, The Social Science Journal, Vol. 38, No. 2, pp. 233-250.

Meyer, J.P. and Allen, N.J. (1997), Commitment in the Workplace: Theory, Research, and Application, Sage, Publications.

Moore, J. E. (2000), One road to turnover: An Examination of Work Exhaustion in Technology Professionals, MIS Quarterly, Vol. 24, No. 1, pp. 141-168.

Mudor,M. and Tooksoon, P. (2011), Conceptual Framework on the Relationship Between Human Resource Management Practices, Job Satisfaction, and Turnover, Journal of Economics and Behavioral Studies, Vol. 2 ,No. 2, pp. 41-49.

Nelson, D.L. and Quick, J.C. (2009), Organizational Behavior ORGB, South-Western Cengage Learning, Mason, Ohio.

Park, J.S. and Kim, T. (2009), Do Types of Organizational Culture Matter in Nurse Job Satisfaction and Turnover Intention? Leadership in Health Services, Emerald Group Publishing Limited, Vol.22, No.1, pp. 20-38.

Passarelli, G. (2011), Employees' Skills and Organizational Commitment, International Business Research, Vol.4, No.1, pp.28-42.

Perera, G.D.N., Khatibi, A., Navarathna N.N.J. and Chinna. K. (2014),Job Satisfaction and Job Performance among Factory Employees in Apparel Sector, Asian Journal of Management Science \& Education, Vol. 3, No.1, pp.96-104.

Raymond H.M. Fok, Ruth M. W. and Yeung, (2016), Work Attitudes of Generation $Y$ in Macau's Hotel Industry: Management's Perspective, Worldwide Hospitality and Tourism Themes, Vol. 8, No. 1, pp.83-96.

Rich, B. L. Lepine, J. A. and Crawford, E. R. (2010), Job Engagement: Antecedents and Effects on Job Performance. Academy of Management Journal, Vol. 53, No.3, pp. 617-635.

Richardson, S. (2009), Undergraduates' perceptions of tourism and hospitality as a career choice, International Journal of Hospitality Management, Vol. 28, No. 3, pp. 382-388.

Robbins, S.P. and Judge, T.A. (2009), Organizational Behavior, $13^{\text {th }}$ ed, Pearson Prentice Hall, Upper Saddle River, NJ.

Rosin, H. M. and Korabik, K. (1991), Workplace Variables, Affective Responses, and Intention to Leave among Women Managers, Journal of Occupational and Organizational Psychology, Vol.64, No.4, pp. 317-330.

Sekaran, U.and Bougie, R. (2010), Research Methods for Business: A Skill Building Approaches, $5^{\text {th }}$ ed. West Sussex, UK: John Wiley \& Sons Ltd.

Shwu-Ru, L. and Ching-Yu, C. (2010), Organizational Climate, Organizational Commitment and Intention to Leave amongst Hospital Nurses in Taiwan, Journal of Clinical Nursing, Vol.11, No.12, pp. 1635-1644.

Solnet, D. and Hood, A. (2011), Generation $Y$ as Hospitality Industry Employees - An Examination of Work Attitude Differences, The University of Queensland Australia and Hospitality Training Association. 
Solnet, D. Kralj, A. and Kandampully, J. (2012), Generation Y Employees: An Examination of Work Attitude Difference, The Journal of Applied Management and Entrepreneurship, Vol. 17 ,No. 3, pp. 35-52.

Stammen, K. (2003), Bank one, Hospital get Psychologically Healthy Workplace Awards in Ohio", Knight Ridder Tribune Business News, Ohio.

Tett, R.P. and Meyer, J.P. (1993), Job Satisfaction, Organizational Commitment, Turnover Intention and Turnover: Path Analyses based on Meta-Analytic Findings, Personnel Psychology, Vol. 46 ,No. 2, pp. 259-293.

Thomas, K. W. and Tymon, W. G. (1994), Does Empowerment always Work: Understanding the Role of Intrinsic Motivation and Personal Interpretation?, Journal of management Systems, Vol. 6, No. 2, pp. 1-13.

Winterton, J. (2004), A Conceptual Model of Labour Turnover and Retention. Human Resource Development International, Vol.7, No. 3, pp. 371-390.

Yucel, I. (2012), Examining the Relationship among Job Satisfaction, Organizational Commitment, and Turnover Intention: An Empirical Study, International Journal of Business Management, Vol. 7, No. 20, pp. 44-57.

\section{ACKNOWLEDGEMENT}

This work was supported by the University of Sri Jayewardenepura research grant ASP/01/RE/MGT/2018/67. 